\title{
The particle $m a$ in Old Sundanese
}

\author{
AdITIA GUNAWAN AND EVI FUJI FAUZIYAH
}

\begin{abstract}
This article will analyse the distribution of the particle ma in Old Sundanese texts. Based on an examination of fifteen Old Sundanese texts (two inscriptions, eight prose texts, and five poems), we have identified 730 occurrences of ma. We have selected several examples which represent the range of its grammatical functions in sentences. Our observations are as follows: (1) ma not only appears in direct dialogues, but also in narrative texts, both prose and verse; (2) ma functions as a copula in nominal sentences, connecting subject and predicate; (3) in conditional clauses containing the conjunction lamun, ma has a function similar to that of mah in Modern Sundanese but, in the absence of lamun and if the supplementary clauses only consist of verb phrases, ma itself is also capable of expressing conditionality; (4) if this particle is preceded by negations such as hamo 'not' or hanto 'there is not' in conditional clauses, $m a$ is placed directly after these negations and does not mark the predicate, but serves instead to stress the negation itself; (5) in the cases described in points 1-4, ma can be considered a topic marker, and in some phrases we have even found the dislocations that are characteristic of topic markers; and (6) ma can appear in imperative sentences, placed immediately after verbs to emphasize commands, which does not apply to mah in Modern Sundanese.
\end{abstract}

KEYWORDS

Particles; ma; Old Sundanese; philology; historical linguistics; syntax.

The authors can be reached at: aditia.gunawan@efeo.net (ADITIA GUNAWAN) and fuji.vi@ gmail.com (EVI FUJI FAUZIYAH). More information about the authors can be found at the end of the article.

(C) 2021 Faculty of Humanities, Universitas Indonesia

ADITIA GUNAWAN AND EVI FUJI FAUZIYAH | DOI: 10.17510/wacana.v22i1.1040. 


\section{INTRODUCTION ${ }^{1}$}

The grammar of Old Sundanese is a field very rarely investigated. Scholars who study linguistic aspects of Old Sundanese have so far focused their attention on morphological (Fatimah Djajasudarma et al. 1990) and lexicographical aspects (Emuch Hermansoemantri et al. 1987; J. Noorduyn and A. Teeuw 2006). Noorduyn and Teeuw (2006: 30-72, 331-429) studied the phonological and morphological system of Old Sundanese and listed the Old Sundanese vocabulary found in the three Old Sundanese poems they edited (see below). Almost no research has been conducted on the syntactic level. This is probably as much because of the dearth of scholars active in this field as to the limited number of Old Sundanese prose texts available. ${ }^{2}$ One of the important morphemes in Old Sundanese, which invites detailed examination, is the particle ma.

We should explain straight away that in Old Sundanese, it is necessary to identify two morphemes ma which have very different grammatical functions. Firstly, ma often occurs as a verbal prefix, to form a stative verb, for example, mojar 'to say' which must be analysed as ma+ujar (compare mojar in Old Javanese), manak (ma+anak) 'having child', and so forth. Secondly, ma appears as an independent particle, which can occupy a variety of positions in a sentence. This second morpheme ma will form the focus of the present study. Noorduyn and Teeuw (2006: 381) briefly discuss the function of ma in their glossary. Apart from Noorduyn and Teeuw, no research has been conducted on $m a$, even though it is a very productive feature of Old Sundanese syntax.

We shall begin by looking at Jonathan Rigg's definition of the particle $m a$ in his pioneering work, A dictionary of the Sunda Language of Java (1862), the first Sundanese dictionary ever published. It is interesting to note that $m a$ is recorded as an entry, while no mention is made of mah (Rigg 1862: 26). This raises the questions of whether Sundanese speakers really pronounced it as ma rather than mah at the time the dictionary was compiled and how they would have written it. One also wonders how attuned Rigg's ear was to hearing a final $/ \mathrm{h} / .^{3}$ Judging from Rigg's description of ma cited below (ma

\footnotetext{
1 Aditia Gunawan's research for this article has been undertaken as part of the project DHARMA "The Domestication of 'Hindu' Asceticism and the Religious Making of South and Southeast Asia" (https:/ / dharma.hypotheses.org), funded by the European Research Council (ERC) under the European Union's Horizon 2020 research and innovation programme (Grant Agreement no. 809994). The authors of this article express their gratitude to Arlo Griffiths, Thomas Conners, Henri Chambert-Loir, Tom Hoogervorst, Marine Schoettel, and Wayan Jarrah Sastrawan for their valuable comments.

2 This situation is quite different from Old Javanese studies, in which a large corpus of texts, primarily parwa (a genre of prose), has been mined as a source of research data by experts such as J. Gonda (1959), E.M. Uhlenbeck (1968, 1970, 1985, 1986, 1987), P.J. Zoetmulder (1982), Dwi Puspitorini (2017), and others. Old Sundanese prose texts are very limited in number and most are in the form of didactic texts containing religious treatises without a plot, while the language of such texts features a rather complex vocabulary.

${ }^{3}$ Note that other lexicographers from this period likewise did not always transcribe the wordfinal $/ \mathrm{h} /$ in the manner we would expect based on the modern language. See, for example, the attestations papoewah (papua), si (sih), and tjengkê (cengkeh) in C.J. Batten's work on Betawi (1868).
} 
instead of mah, bogah instead of boga) and other entries in his dictionary, /h/ often occurs where we do not expect it or vice-versa. Either way, it is clear that $m a$ is used in Old Sundanese texts, while mah is only found in a text which is considered to date from a relatively late period (that is, the eightteenth century), the Carita Waruga Guru - and even there, mah only appears once. According to Rigg (1862: 261),

$m a$ [is] an expletive particle which has its force in composition. But [it] admits of no definite translation. Imahna ma hadé, "as to his house, it is good". It will often answer to the English expression "as far as, as to". Sia ma tilok bisa bogah urusan, "as for you, you can never come right". Kalakuannana éta ma teu meunang diwada, "as far as his conduct is concerned, you cannot find fault with it." [Square brackets and quotation marks are from the present authors.]

Later dictionaries no longer include ma, but only mah. A. Geerdink (1875, s.v. mah), for instance, notes that mah serves to make a contrast, has no meaning of its own and emphasizes the word after which it appears. The same idea was followed by Sierk Coolsma (1913, s.v. mah), who stated that mah is a marker of emphasis placed behind the word, clause or sentence to which it refers, producing a contrast by placing a strong emphasis on it. ${ }^{4}$

The function of particles such as mah, téh, and téa has also rarely been discussed in grammars of Modern Sundanese. The scholar Coolsma, whom we have just cited, expressed the idea that mah puts strong stress on a word, phrase, or sentence, therefore expressing a contrast (1904: 266). Sundanese scholars, among whom D.K. Ardiwinata (1916) and R. Momon Wirakusumah and I. Buldan Djajawiguna (1957), have identified mah as an emphatic particle (kecap panganteb). R.R. Hardjadibrata (1985:33) distinguished these particles (namely, mah, téh, téa, et cetera) from other particles, categorizing them as "emphatic markers" or "phrasal markers", but have not discussed their functions or give any examples. Yayat Sudaryat et al. (2007) made the same argument as Coolsma, explaining that mah is an emphatic word which functions as a comparative (babandingan), to emphasize that something is important. In short, all linguists seem to agree that mah is an emphatic particle and some have argued that it can serve to introduce a contrasting or a comparative situation in a sentence.

A specific discussion of the particle mah in Modern Sundanese was offered by Franz Müller-Gotama (1994: 236, see 1996: 117) in two important articles, in which he explained:

[...] mah is shown to be a focus marker introducing new or contrastive information, téh a marker of known, topical information, and téa a marker indicating that a previously mentioned participant is being reintroduced into the discourse. Structurally, mah and téh adjoin to the right of any maximal constituent, while téa behaves like a special kind of determiner.

${ }^{4}$ Original quote: "een nadruk wijzer die geplaatst wordt achter het woord, het zinsdeel of den zin waarop hij betrekking heeft, en die door den sterken nadruk dien hij daarop legt, een tegenstelling vormt". 
Most recently, Masashi Furihata (2019) has identified mah as a contrastive topic marker through the analysis of the intonation of Sundanese speakers. He concluded that in topic-comment order, the pitch movement of the phrases with mah showed a greater rise before the topic marker, whereas that of the phrases with téh showed a rise at the topic marker.

The particle ma in Old Sundanese can be considered the direct predecessor of modern mah. Noorduyn and Teeuw (2006: 381), the only scholars who have discussed the particle, provide the following note:

$m a[. .$.$] an emphatic particle expressing contrast, always occurring in dialogues,$ MSd. [i.e. Modern Sundanese] mah 'id.'; aya ma [...] 'if there are'.

It is noteworthy that Noorduyn and Teeuw do not outline any differences between ma in Old Sundanese and mah in Modern Sundanese. They also mention that, in their three texts, ma only appears in dialogues.

The rest of this article aims to address the following questions: Does the particle $m a$ in Old Sundanese indeed have the same function as mah in Modern Sundanese? If not, how do they differ? To answer these questions, we shall analyse the distribution and function of the particle $m a$ in dialogues, nominal sentences, conditional clauses, conditional clauses with negation, and imperative constructions.

\section{Distribution in Old Sundanese texts}

There are 730 occurrences of the particle $m a$ in the corpus of Old Sundanese texts which we have collected. The sources used for analysis are thirteen texts which have been edited on the basis of manuscripts and furnished with a translation, among which eight are in prose and five in verse, plus two inscriptional texts. ${ }^{5}$ Considering that it is almost impossible to determine the chronological frame of Old Sundanese texts, the following list of texts is arranged alphabetically. ${ }^{6}$

BM: Bujanga Manik (poem, ca. fifteenth century, in Noorduyn and Teeuw 2006)

CP: $\quad$ Carita Parahyanan (prose, prior to 1600, in Atja and Saleh Danasasmita 1981a)

FCP: Fragmen Carita Parahyanan (prose, prior to 1600, in Undang A. Darsa and Edi S. Ekadjati 2001)

KAW: Kawali inscriptions (prose, ca fourteenth century, Aditia Gunawan and Arlo Griffiths Forthcoming)

\footnotetext{
${ }^{5}$ Even though the genres are different, we found that, in the context of $m a$, the syntactic structures are all the same, so the differences in text type do not affect the final result.

${ }^{6}$ In general, the quotes of texts and translations follow the published editions, even though we have taken the liberty of amending these, wherever the published versions have seemed imprecise. These revisions are marked wherever possible.
} 
KEB: Kebantenan inscriptions (prose, circa fifteenth century, Aditia Gunawan and Arlo Griffiths Forthcoming)

KP: Kawih Paninkas (poem, prior to 1500, in Undang A. Darsa and Edi S. Ekadjati 2006)

Paby: Pabyantaraan (prose, prior to 1500, in Mamat Ruhimat et al. 2014)

RR: $\quad$ The Sons of Rama and Rawana (poem, ca. fifteenth century, in Noorduyn and Teeuw 2006)

SD: $\quad$ Sewaka Darma (Kawih Pañaraman) (poem, ca. fifteenth century, in Saleh Danasasmita et al. 1987)

SJMP: San் Hyan் Jati Maha Pitutur (prose, prior to 1600, in Tien Wartini et al. 2010)

SSC: $\quad$ San் Hyan் Swawar Cinta (poem, prior to 1600, in Tien Wartini et al. 2011)

SSKK: San் Hyan் Siksa Kandan Karasian (prose, prior to 1500, in Atja and Saleh Danasasmita 1981b)

SSMG: San் Hyan் Sasana Mahaguru (prose, prior to 1500, in Aditia Gunawan 2009) TB: $\quad$ Tutur Bwana (prose, prior to 1600, in Tien Wartini et al. 2010)

Archaeologists assume that the Kawali inscriptions were produced during the fourteenth century, while the Kebantenan inscriptions date from the fifteenth. Meanwhile, almost no Old Sundanese texts mentions a precise date, with the exception of the manuscript which contains the text San Hyan Siksa Kandan Karasian (Cod. L 630 Perpusnas, Jakarta). According to Aditia Gunawan and Arlo Griffiths (2014), this manuscript is the oldest Old Sundanese text which records a date in the colophon, and it was written in the year 1440 Saka (1518 $\mathrm{CE})$. Nevertheless, it may be assumed that all the above sources were written before the sixteenth century. The time span covered by the data in our corpus therefore corresponds to the fourteenth, fifteenth, and sixteenth centuries.

\subsection{Dialogues}

As stated by Noorduyn and Teeuw (2006: 381), the particle ma often emerges in direct dialogue, as shown in sentences (1)-(5).

(1) N-embal Prabu Puspalawa, "Lancək-in,, ain ma n-urut". ACT-answer king PR brother-1POSS 1SG PRT ACT-follow 'King Puspalawa answered: "My brother, I shall follow".' (RR.534)

(2) Utun Probu Manabaya, eta ma tuá pajurit pamraran Ratu Rawana son king PR that PRT 2POSS soldier warrior king PR 'My son, King Manabaya, they are your soldiers, King Rawana's warriors.' (RR.925)

(3) Is ma diga si utun, diga Raden Megananda this PRT alike HON son alike PR 'This [boy] looks like [my] son, like Raden Megananda.' (RR.1031) 
(4) Anak-in, Sàं Rasi Putih, kita ma ka-duum-an Rasisasana child-1POSS HON PR 2SG PRT PASS-give-LOC Rəsisasana

'My child, Resi Putih, you are given the Resisasana [precepts of the sage].' (FCP.26b)

(5) Baruk ma dayəhan dalam, nu $\dot{n}$-əsi na kadaton evidently PRT inhabitant palace, REL ACT-fill ART palace

'Evidently, they are the inner-court habitants, who fill the palace.' (RR.226)

Sentences (1) to (5) fit Noorduyn and Teeuw's observation that the particle $m a$ is used in direct speech, in the utterances of characters of the story. In the sentences (1)-(5), ma is found both in prose (FCP) and verse (RR). Sentence (2) is uttered by Aki Sombali to Manabaya, whereas sentence (3) is spoken by King Bibisana to Sombali. In this discourse environment, ma shows that the information introduced is new. In sentence (4), for example, the Resi Putih had just been introduced, and the same is true for the dayzhan dalam 'innercourt habitants' in sentence (5). This syntax construction corresponds to the modern usage of the particle mah (Müller-Gotama 1996: 117-132).

In prose texts, we also find sentences with particle ma in narrative contexts, as in sentences (6)-(10). Nevertheless, it is important to note that some features of direct speech are present in these sentences. Sentences (6), (8), and (10), for instance, are from a didactic text, in which a teacher speaks to his/her pupil(s), as a first-person narrator talking to a second-person addressee.

(6) Paksa ma cai, alazn-ana ma basana bijil ti hulu-na intention PRT water benefit-POSS PRT when appear from source-POSS 'Intention is water, its benefit is when it appears from its source.' (SSMG.1)

(7) N-əmu darma ti Aki ma k-an̈kan guru kaki ṅaran-na ACT-find virtue from grandfather PRT PASS-call PR name-POSS

'Finding virtue from the grandfather is called guru kaki by name.' (SSKK.12)

(8) Batara Guru di Jampang ma iña nu ñ-ian rukuh San Hyan Pake $\begin{array}{lll}\text { PR } & \text { PREP PR PRT 3SG REL ACT-make crown PR }\end{array}$

'Lord Guru in Jampang, it is he who made the crown San Hyan Pake.' (FCP.21a)

(9) Bagawat Cinta Putih ma siya di-adog-kan batara di Gagar Gadun PR PRT 3SG PASS-stand-CAUS lord PREP PR

'Bagawat Cinta Putih, it is he who has been established [as] deity in Geger Gadung.' (FCP.10b)

(10) Ini ma iña na ka-tuhu-kan-ən nu di-pajar trikaya this PRT 3SG ART PASS-follow-PASS-NOM REL PASS-call PR

'This is what has to be followed, what is called trikaya.' (SSMG.20) 
The particle ma can occur in simple or complex sentences. The preceding element can be complex, as shown in the verb phrase nomu darma ti aki ma (7). In such complex sentences, $m a$ is always placed in the first clause and functions as a marker between clauses, marking the subject and topicalizing it. It is worth noting that examples (8)-(10) contain cases of dislocation. This term designates a sentence structure in which a referential constituent functioning as an argument or an adjunct within a predicate-argument structure occurs outside the boundaries of the clause containing the predicate, either to the left (left-dislocation) or to the right (right-dislocation) (Knud Lambrecht 1994: 1050).

\subsection{NOMINAL SENTENCES}

The particle ma typically appears after a noun. In nominal sentences, it separates subject and predicate.

(11) Pañca ma watzk lima, we ma cai dani ma sapuñere PR PRT category five PR PRT water PR PRT broomstick

'Pañca means five categories, we means water, dani means broomstick.' (SSMG.1)

(12) Tiga ta ma tolu, sadana ta ma drabya

PR PRT $^{7}$ PRT three PR PRT PRT wealth

'Tiga means three, sadana means wealth.' (SSMG.3)

(13) Kalapa bajra ma na pañadap, latak si Balagada ma pañawah Palm-tree PRT ART tapper mud HON PR PRT rice farmer

'[One who deals with] palm-trees is the tapper, [with] mud is called Balagada a rice-farmer.' (SSMG.5)

(14) Ñan-carut-kan maneh ma naranya: nu aya di-pajar ACT-REFL-defile PRT called REL exist PASS-consider

Hanto nu hanto di-pajar waya not.exist REL not.exist PASS-consider exist

'Defiling yourself means: that which exists is considered to be non-existent, that which does not exist is considered existent.' (SSKK.5)

In nominal sentences (11)-(13) the particle ma separates subjects from predicates, yet in sentence (14) it is placed after the verb phrase and verb clause. In these cases, ma functions as a copula. Sentences (11)-(12) merit some contextualization. Before the author explains the terms pañca, we, and dani,

\footnotetext{
7 The particle $t a$ in this sentence seems to have a similar function as the same particle has in Old Javanese (Zoetmulder 1982, s.v.), but a relation with MdS tamah (a contraction of the particles éta and mah) is also imaginable. The latter option would, however, not change the meaning of the sentence. A further study of the particle $t a$ in Old Sundanese texts is desirable, but beyond the scope of this article.
} 
the previous sentence clarifies that nihan sinanguh pañcawedani ("here follows what is called pañcawedani"), while sentence (12) is preceded by ini tiga di san pandita, naranna tiga sadana ("these three are in the sage, they are called tiga sadana"). As such, it appears that, besides emphasizing new and contrastive information, ma can also introduce elaborations.

\subsection{CONDITIONAL ClAUSES}

In the corpus we collected, the particle ma mainly appears in conditional clauses. In this conditional construction, ma can be accompanied by the conjunction lamun 'if' (15-17) but it can also stand-alone (18-22).

(15) Lamun dek ñaho di puhun suka lawan enak ma if want know PREP source enjoyment and pleasure PRT

inat-kan saur san darma pitutur

remember-CAUS word HON PR

'If [one] wishes to know the source of enjoyment and pleasure, remember the words of Darma Pitutur.' (SSKK.15)

(16) Lamun-na $k a$ lamah ma tiis dinin paripurna if-POSS to ground PRT cold cool perfectly

'If [it falls] to the ground, it will become perfectly cool [and] cold.' (TB.36A.4)

(17) Lamun-na di-pi-təmen ma na adrasya, sañkan ka-birən்h

if-POSS PASS-real PRT ART Invisible so.that PASS-reveal

dəi ka-jəə⿳亠口冋 raga dəi

again PASS-see body again

'If the invisible is realized, so that it will be revealed again, the body will be visible again.' (SJMP.2)

(18) Datain ma kita ka dalam, mulah salah m-awa beja arrive PRT you to palace PROH wrong ACT-bring news 'If you arrive at the palace, do not err in delivering news.' (BM.582)

(19) $\dot{N}$-impi rwadek ma, sakit-an kita ACT-dream ugly PRT ill-LOC you

'If [you] have a nightmare, you will become sick.' (Paby.27r)

(20) Aya ma na uran் nu ka-sasal ku tohaan, eta keh ulah exist PRT ART people REL PASS-scold by lord that PRT PROH di-turut twah bisi uran ka-sasal dai PASS-follow conduct for 1PL PASS-scold also

'If someone is being scolded by the lord, their actions should not be followed, for we shall also be scolded.' (SSKK.10) 
(21) Hayan ñ-aho di lwir-nin lawə⿱亠 ma gajah taña want ACT-know PREP type-POSS forest PRT elephant ask 'If [one] wishes to know the types of jungle, ask the elephant.' (SSKK.15)

$\begin{array}{lllll}\text { Angəs ma } & \text { ka-pahayu } & \text { dora sapuluh, rampes twah-na } \\ \text { already PRT } & \text { PASS-maintain gate ten good conduct-POSS } \\ \text { uran reya } & & & & \\ \text { people a.lot } & & & \end{array}$

'If the ten gates [of the body] have been maintained, the conduct of people at large will be good.' (SSKK.2)

(23) Lun ain to di-aku anak, kita ma paraiatna

if 1SG NEG PASS-claim son you PRT be.careful

'If I am not acknowledged as a son, you must be careful!' (RR.1237)

In sentences (15) to (17), the particle ma is preceded by the conjunction lamun 'if', which connects two clauses as a conditional conjunction. The clause containing the conjunction is the condition of an event, which is itself explained in the clause following it. This construction can also be applied to sentences which do not contain conjunction lamun (18-21), in which we see that ma itself is also capable of expressing conditionality. In other words, if the condition is $X$ (with or without conjunction) $+m a$, then Y occurs or is expected to be occurred. In these cases, the particle ma marks the predicate in the topic. Sentence (22) is a slightly complex case, because $m a$ is placed in the predicate in one verbal phrase (aingas ma kapahayu). It is a temporal marker which receives ma and it shows a similar tendency with cases in Section 2.4, in which ma is placed after a negation. In other word, if the verb is modified with an adverbial marker or negation, the position of $m a$ can shift from verb to modifier. However, we find an anomaly in sentence (23), where ma occurs in the second clause, not in the dependent clause containing lun (shortened form of lamun) 'if', and this is likely in response to the requirements of the octosyllabic verse.

\subsection{CONDITIONAL CLAUSES WITH NEGATION}

In conditional clauses, the particle can also be preceded by a word expressing negation, such as hamo 'not' or hants 'there is not', but in this case, ma directly follows the negation word, not the complement clause. The sentences (24)-(26) show these characteristics.

$$
\begin{aligned}
& \text { Hanta ma n-urut na pamagahan, eta sarua dərin sakalih } \\
& \text { not.exist PRT ACT-follow ART advice that same as other.people } \\
& \text { 'If one does not follow the advice, it is the same as other people.' }
\end{aligned}
$$


(25) Lamun hamo ma bisa ía-labur iña ina-latik-kən

if NEG PRT capable ACT-pulverize 3SG ACT-small-CAUS

rasa, $\quad \dot{n a-r a g a}$ doi $k a$ sakala

intention ACT-body again to manifest.world

'If one is not able to pulverize himself, diminishing the intention, [he] will incarnate again into the manifest world.'

(26) Lamun hamo ma bisa n-urut pamagahan pungun tata if NEG PRT capable ACT-follow advice ignorance rule naran-na

name-3POSS

'If one cannot follow the advice, it is called pungun tata (ignorance of rules).' (TB.31B)

In addition, the sentences (27)-(32) show a pattern in which the particle ma is placed not in the first clause but in the second, and appears after the negation mo (short for hamo).

(27) Mo ñ-oran pi-carek dai, mo ma ti na pañimpian

NEG ACT- experience NOM-converse again NEG PRT in ART dream

'[We] shall never have the conversation again, if not in a dream.' (BM.547-548)

(28) Ka saha gasan na-hiras, di sakala di

to who place ACT-seek.for.help PREP material world PREP

niskala, mañuni di kahyañan, mo ma di

immaterial world also PREP residence of Gods NEG PRT PREP

na laku tuhu na jati mahapandita

ART deed right ART nature great sage

'To whom shall I ask help, in the material and immaterial world, also in the residence of the Gods, if not to the right virtue, the nature of great sages.' (Kaw Pani.27)

(29) Mo m-ere mo ma kadaek, gantal siratu manilayan, mo NEG ACT-give NEG PRT will betel.leaf PR NEG

m-ere mo ma ka-hayang

ACT-give NEG PRT NOM-wish

'[I] shall not give, if it is not [your] will, the betel leaves [called] siratu manilayan,

[I] will not give [them], if it is not [your] wish.' (BM.480-482)

(30) Cali ulah baran-deñe mo ma nu siap di-deñe, kenana ear PROH ACT-listen NEG PRT REL proper PASS-listen for

dora bañcana

gate suffering

'Ears should not listen, if [the topic] is not proper to be listened to, for [that is] the gate of suffering.' (SSKK.1) 
(31) Ah ain m-ran mo suka mo ma ain angas

INTERJ 1SG ACT-fight NEG happy NEG PRT 1SG already

na-rompek-kən Gunun Kahyaian

ACT-ruined-CAUS mount PR

'Ah, I am not happy to fight, if I have not yet destroyed Mount Kahyanan.' (TB.27b)

$\begin{array}{llllll}\text { Hih } & \text { Darmajati ta, mo ain } & \text { oron } & \text { na-hori-kan, } & \text { mo ma } \\ \text { INTERJ PR } & \text { PRT NEG } 1 S G & \text { stop } & \text { ACT-disturb-CAUS NEG PRT } \\ \text { ain añgas } & \text { di-sorga-kən } & k u & \text { San் Darmajati } & \\ \text { 1SG already } & \text { PASS-heaven-CAUS by } & \text { PR }\end{array}$

'Hey, Darmajati, I shall not stop disturbing [you], as long as I am not yet placed in heaven by Darmajati.' (TB.31B)

It is interesting to note here that the particle $m a$ is not found in the first clause. Instead, sentences (27)-(32) show that it marks an exception; for example, in sentence (32), the subject ("I") would not be happy unless "I" had destroyed Mount Kahyangan. Still following the pattern of conditional clauses discussed in Section 2.3 and of negated conditional clauses with conjunction lamun seen in (24)-(26), mo ma can be translated naturally as 'if not (yet)'. In certain cases, this can be represented more idiomatically with "unless, until". Noorduyn and Teeuw (2006) list moma as a separate entry in the glossary - in the form of the construction "mo ... moma" - and consider mo ma an indivisible word. However, sentences (28) and (30) show that mo ma is not always preceded by the negation mo.

\subsection{IMPERATIVE SENTENCES}

The particle $m a$ is also attested after imperative verbs. Imperative forms in Old Sundanese can be marked by the absence of prefixed on verbs. In the following sentences, the non-prefixed verbs are baan 'to bring', balun 'to wrap', and bawa 'to take'.

(33) Baan ma ka pamangahan!

bring PRT to gallows

'Bring [her] to the gallows!' (RR.239)

(34) Asup-kan ka karastulis, balun ma ku boeh laran enter-IMP to ornate box wrap PRT with sacred cloth

'Put [her] into the ornate box, wrap it with sacred cloth!' (RR.252)

(35) Jompon sia pulan doi, ini bawa pañirim-in, bawa ma PR 2SG go back again this take parcel-1POSS take PRT

ka tuan ambu!

to POSS.2SG mother

'Jompong, you should go back home, here, take my parcel, take it to your mother!' (BM.398) 
Sentences (33)-(35) show that ma gives emphasis to imperative verbs, which it follows directly in a manner similar to the use of -lah in imperative clause in Malay. Sentence (33) is uttered by Rama who orders his troops to take Sita to the gallows (implying: not anywhere else). In (34), when Sita is put in a casket, Laksamana requests that the casket be wrapped in boeh raran (sacred cloth). Noticing this precious fabric in the river, the elder protagonist Hayam Cangon, becomes suspicious and finally saves her.

One wonders here whether the emergence of $m a$ is because of the requirements of octosyllabic metrics, considering that we find these occurrences exclusively in verse texts. However, to the best of our knowledge, the use of mah is never found in imperative sentences in Modern Sundanese, so this imperative construction is a particularity of Old Sundanese.

\section{PRACTICAL IMPLICATIONS}

Our examination of the grammatical functions of $m a$ in Old Sundanese can contribute to the editing of Old Sundanese texts and help to gain a more accurate understanding of the meaning of the sentences which contain this particle. An interesting example is the interpretation of the last sentence in one of the Kawali inscriptions. As given in $\left(36^{\prime}\right)$ are two interpretations which epigraphists have offered of its meaning.

(36') Aya ma nu pa(n)dari pake na gawe rahayu pakan habal jaya di na buana (Kawali I)

(i) 'To those who will come next, they should apply welfare as the foundation of the victory of life in the world ${ }^{10}$ (Richadiana Kartakusuma 2005: 49).

(ii) 'May there be a successor who will carry out good deeds so that they will be glorious in the world for a long time ${ }^{11}$ (Titi Surti Nastiti 1996: 21).

Referring to the functions of the particle $m a$ as outlined in this article and the construction of Old Sundanese imperative sentences, our interpretation would be as in (36).

(36) Aya ma nu pa(n)dari pake na gawe rahayu pakən habal jaya exist PRT REL posterity use ART deed good for long glory

di na buana

PREP ART world

'If there is a successor, do good deeds for everlasting glory in the world.' (Kawali I)

\footnotetext{
${ }^{9}$ All previous scholars who have studied the Kawali inscriptions treat the article $n a$ as the suffix -na, and therefore give pakena as one word (see Noorduyn 1976; Titi Surti Nastiti 1996; Richadiana Kartakusuma 2005). On the function of $n a$ as a definite article, see Noorduyn and Teeuw (2006) and Hardjadibrata (2003: s.v. na 5).

${ }^{10}$ Original translation in Indonesian: 'Kepada yang akan datang, hendaknya menerapkan keselamatan sebagai landasan (ke)menang(an) hidup di dunia'.

${ }^{11}$ Original translation in Indonesian: 'Semoga ada penerus yang melaksanakan berbuat kebajikan agar lama jaya di dunia'.
} 
In this inscription, the particle ma marks conditionality. In this case, the condition is the presence (aya) of a successor to the King mentioned in the inscription, Prabu Raja Wastu. This hypothetical successor receives an order (marked by imperative verb pake) to perform an action (marked by article na as a definite article modifying gawe rahayu 'good deeds') in order that he might receive everlasting glory in the world. Another example containing a similar construction is found in the Kebantenan I inscription, as analysed in (37).

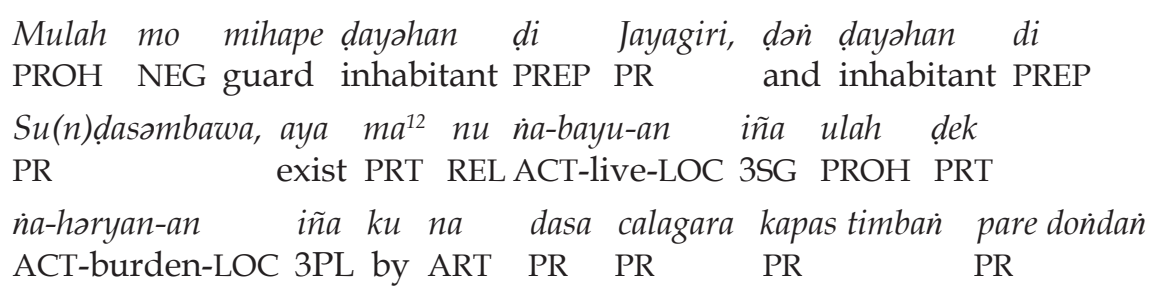

'Do not fail to guard the inhabitants of Jayagiri and the inhabitants of Sundasembawa. If there are people who support them, do not burden them by dasa, calagara, cotton timban, rice dondan' ${ }^{13}$

Another example of a nominal sentence construction featuring $m a$ is found in the Kebantenan II and IV inscriptions.

$\begin{array}{lllll}\text { (38) } & \mathrm{Nu} & \text { di-pitakat-an } & \text { ma na lamah dewasasana } \\ \text { REL } & \text { PASS-decree-LOC PRT ART land PR }\end{array}$

'The place which has been made the subject of a decree is the land of dewasasana.'

Both Boechari (1985) and Hasan Djafar (1991) transliterated ma na as a single word mana and proposed emending this to nana, to obtain dipitakatannana. By considering the use of ma in nominal sentences (see Section 2.2), however, it is clear that the above sentence does not need to be emended at all.

\section{CONCLUSION}

After conducting a descriptive analysis of the particle ma in Old Sundanese, we have found, unsurprisingly, that there are considerable similarities between the function of ma in Old Sundanese and that of the particle mah in Modern Sundanese. None the less, some differences have also come to light. With regard to its use in Old Sundanese, we have found that: (1) ma not only appears in direct dialogue, but also in narrative contexts both in prose and verse; (2) ma functions as a copula in nominal sentences, connecting subject and predicate; (3) in conditional clauses containing the conjunction lamun, ma has a function similar to that of mah in Modern Sundanese, but in the absence of

\footnotetext{
${ }^{12}$ Boechari (1985) transcribes aya ma as a single word ayama.

${ }^{13}$ These four terms appear to refer to taxes and/or penalties. The dasa might relate to a tax on slave ownership (<Sanskrit dāsa 'slave', see Old Javanese-English dictionary: s.v. dāsa 'id'.); calagara is the regular Sundanese cognate of Old Javanese walagara 'the corresponding contribution (to obtain permission) or penalty' (see Zoetmulder 1982, s.v. walagara); kapas timban and pare donda seem to refer to cotton (kapas) and rice (pare) in certain units: timbain and dondan.
} 
lamun and if the supplementary clauses consist only of verb phrases, ma itself is also capable of expressing conditionality; (4) if this particle is preceded by negations such as hamo 'not' or hanta 'there is not' in a conditional clause, ma is placed directly after the negation, does not mark the predicate, but serves to stress the negation itself; (5) in the cases described in points (1)-(4), ma can be considered a topic marker, and in some phrases we have even found the dislocations which are characteristic of topic markers; and (6) ma can appear in imperative sentences, placed immediately after verbs to emphasize commands, which does not apply to mah in Modern Sundanese. Cumulatively, these findings are expected to help editors of Old Sundanese to work with the texts they are facing. Further linguistic research into Old Sundanese data is desirable to fill the many remaining gaps in this field.

\section{AbBREVIATIONS}

In the analysis of Old Sundanese examples, we use simple Leipzig glossing rules (Bernard Comrie et al. 2015). The following are several terms we use to describe the quoted Old Sundanese sentences.

$\begin{array}{ll}1 & \text { first person } \\ 2 & \text { second person } \\ 3 & \text { third person } \\ \text { ACT } & \text { active voice } \\ \text { ART } & \text { article } \\ \text { CAUS } & \text { causative } \\ \text { DEF } & \text { definite } \\ \text { HON } & \text { honorific } \\ \text { INTERJ } & \text { interjection } \\ \text { LOC } & \text { locative } \\ \text { NOM } & \text { nominalizer } \\ \text { PASS } & \text { passive voice } \\ \text { PL } & \text { plural } \\ \text { POSS } & \text { possessive } \\ \text { PREP } & \text { preposition } \\ \text { PR } & \text { proper noun } \\ \text { PROH } & \text { prohibitive } \\ \text { PRT } & \text { particle } \\ \text { REFL } & \text { reflexive } \\ \text { REL } & \text { relative particle } \\ \text { SG } & \text { singular }\end{array}$

\section{REFERENCES}

Aditia Gunawan. 2009. Sanghyang Sasana Maha Guru dan Kala Purbaka; Suntingan dan terjemahan. Jakarta: Perpustakaan Nasional Republik Indonesia.

Aditia Gunawan and Arlo Griffiths. 2014. "The oldest dated Sundanese manuscript; An encyclopedia from West Java, Indonesia". [Manuscript of the Month; https://www.manuscript-cultures.uni-hamburg.de/ mom/2014_03_mom_e.html.] 
Aditia Gunawan and Arlo Griffiths. Forthcoming. "Old Sundanese inscriptions; Renewing the philological approach".

Ardiwinata, D.K. 1916. Elmuning basa Sunda pikeun pangajaran di sakola2. Weltevreden: Indonesische Drukkerij.

Atja and Saleh Danasasmita. 1981a. Carita Parahiyangan; Transkripsi, terjemahan dan catatan. Bandung: Proyek Pengembangan Permuseuman Jawa Barat.

Atja and Saleh Danasasmita. 1981b. Sanghyang Siksakanda ng Karesian (naskah Sunda Kuno tahun 1518 Masehi). Bandung: Proyek Pengembangan Permuseuman Jawa Barat.

Batten, C.J. 1868. De djoeroe basa Betawi; Eenvoudige Bataviaasch-Maleische woordenverzameling. Batavia: Van Dorp.

Boechari. 1985. Prasasti koleksi Museum Nasional, Jilid I. Jakarta: Proyek Pengembangan Museum Nasional, Departemen Pendidikan dan Kebudayaan.

Comrie, Bernard, Martin Haspelmath, and Balthasar Bickel. 2015. "'Leipzig Glossing Rules', 31 May 2015”. [Retrievable: https://www.eva.mpg.de/ lingua/resources/glossing-rules.php.]

Coolsma, Sierk. 1904. Soendaneesche spraakkunst. Leiden: A.W. Sijthoff.

Coolsma, Sierk. 1913. Soendaneesch-Hollandsch woordenboek. Second edition. Leiden: A.W. Sijthoff.

Dwi Puspitorini. 2017. Afiks verbal bahasa Jawa Kuno. PhD thesis, Universitas Indonesia.

Emuch Hermansoemantri, A. Marzuki, and Elis Suryani N.S. 1987. Kamus bahasa Sunda Kuna-Indonesia. Bandung: Proyek Penunjang Sundanologi, Dinas Pendidikan dan Kebudayaan, Pemerintah Propinsi Daerah Tingkat I Jawa Barat.

Fatimah Djajasudarma, Idin Baidillah, and Undang Ahmad Darsa. 1990. Carita Parahyangan; Satu kajian struktur bahasa Sunda dialek temporal. Bandung: Proyek Penelitian dan Pengkajian Budaya Sunda (Sundanologi), Dinas Pendidikan dan Kebudayaan, Pemerintah Propinsi Daerah Tingkat I Jawa Barat.

Furihata, Masashi. 2019. "An analysis of pitch movement of sentences with topic markers in Sundanese", Southeast Asian Studies Tokyo University of Foreign Studies 24: 80-99.

Geerdink, A. 1875. Soendaneesch-Hollandsch woordenboek. Batavia: Van Dorp.

Gonda, J. 1959. “On Old-Javanese sentence structure”, Oriens Extremus 6(1): 57-68.

Hardjadibrata, R.R. 1985. Sundanese; A syntactical analysis. Canberra: Department of Linguistics, Research School of Pacific Studies, Australian National University. [Pacific Linguistics D 65; Materials in Languages of Indonesia 29.]

Hardjadibrata, R.R. 2003. Sundanese English dictionary. Jakarta/Bandung: PT Dunia Pustaka Jaya and Kiblat Buku Utama.

Hasan Djafar. 1991. "Prasasti-prasasti dari masa kerajaan-kerajaan Sunda". [Paper, Seminar Nasional Sastra dan Sejarah Pakuan Pajajaran, Bogor, 11-13 November.] 
Lambrecht, Knud. 1994. Information structure and sentence form; Topic, focus, and the mental representations of discourse referents. Cambridge: University Press. [Cambridge Studies in Linguistics 71.]

Mamat Ruhimat, Aditia Gunawan, and Tien Wartini. 2014. Kawih Pangeuyeukan; Tenun dalam puisi Sunda Kuna dan teks-teks lainnya. Jakarta: Perpustakaan Nasional Republik Indonesia in cooperation with Pusat Studi Sunda. [Seri Naskah Kuna Nusantara 11.]

Momon Wirakusumah, R. and I Buldan Djajawiguna. 1957. Kandaga; Tatabasa Sunda. Bandung: Ganaco.

Müller-Gotama, Franz. 1994. "The Sundanese particles teh, mah, and tea”, in: K.L. Adams and T.J. Hudak (eds), Papers from the Second Annual Meeting of the Southeast Asian Linguistics Society, pp. 235-250. Tempe, AZ: Program for Southeast Asian Studies, Arizona State University.

Müller-Gotama, Franz. 1996. "Topic and focus in Sundanese”, Anthropological Linguistics 38(1): 117-132.

Noorduyn, J. 1976. “Preliminary report on archaeological research conducted in West Java and East Java in June, July, and August 1976" . [Leiden: KITLV archives.]

Noorduyn, J. and A. Teeuw. 2006. Three Old Sundanese poems. Leiden: KITLV Press. [Bibliotheca Indonesica 29.]

Richadiana Kartakusuma. 2005. "Situs Kawali; Ajaran Sunda dalam tradisi megalitik?", in: Ajip Rosidi (ed.), Islam dalam kesenian Sunda dan kajian lainnya mengenai budaya Sunda, pp. 42-54. Bandung: Pusat Studi Sunda. [Seri Sundalana 4.]

Rigg, Jonathan. 1862. A dictionary of the Sunda language of Java. Batavia: Lange and Co. [Verhandelingen van het Bataviaasch Genootschap van Kunsten en Wetenschappen 29.]

Tien Wartini, Mamat Ruhimat, and Aditia Gunawan. 2011. Sanghyang Swawarcinta; Teks dan terjemahan. Jakarta: Perpustakaan Nasional RI and Pusat Studi Sunda.

Tien Wartini, Ruhaliah, Rahmat Sopian, and Aditia Gunawan (eds). 2010. Tutur Bwana dan empat mantra Sunda Kuna. Jakarta: Perpustakaan Nasional RI and Pusat Studi Sunda.

Titi Surti Nastiti. 1996. "Prasasti Kawali", Jurnal Penelitian Balai Arkeologi Bandung 4: 19-37.

Uhlenbeck, E.M. 1968. "Personal pronouns and pronominal suffixes in Old Javanese", Lingua 21: 466-482. [Retrievable: https:/ / doi.org/10.1016/00243841(68)90069-7.]

Uhlenbeck, E.M. 1970. "Position and syntactic function of the particle $t a$ in Old Javanese", in: R. Jakobson and S. Kawamoto (eds), Studies in general and oriental linguistics presented to Shiro Hattori, pp. 648-658. Tokyo: TEC Corporation for Language and Educational Research.

Uhlenbeck, E.M. 1985. “The concept of proportionality; Old Javanese morphology and the structure of the Old Javanese word kakawin", in: Sulastin Sutrisno, Darusuprapta, and Sudaryanto (eds), Bahasa, sastra, budaya, pp. 66-82. Yogyakarta: Gadjah Mada University Press. 
Uhlenbeck, E.M. 1986. “Clitic, suffix, and particle; Some indispensable distinctions in Old Javanese grammar", in: C.M.S. Hellwig and S.O. Robson (eds), A man of Indonesian letters, pp. 334-341. Dordrecht/Cinnaminson, NJ: Foris. [Verhandelingen van het Koninklijk Instituut voor Taal-, Land- en Volkenkunde 121.]

Uhlenbeck, E.M. 1987. "Sentence patterns in the Old Javanese of the Parwa literature", in: D.C. Laycock and W. Winter (eds), A world of language; Papers presented to Professor S.A. Wurm on his 65th birthday, pp. 695-708. Canberra: The Australian National University. [Pacific Linguistics C-100.] Undang A. Darsa and Edi S. Ekadjati. 2001. "Fragmen Carita Parahyangan dan Carita Parahyangan (Kropak 406)", Seri Sundalana 1, pp. 173-208. [Bandung: Yayasan Pusat Studi Sunda.]

Undang A. Darsa and Edi S. Ekadjati. 2006. Gambaran kosmologi Sunda (kropak 420); Silsilah Prabu Siliwangi, Mantera Aji Cakra, Mantera Darmapamulih, Ajaran Islam (kropak 421); Jatiraga (kropak 422); Studi pendahuluan, transliterasi, rekonstruksi, suntingan, dan terjemahan teks. Bandung: Kiblat Buku Utama. Yayat Sudaryat, Abud Prawirasumantri, and Karna Yudibrata. 2007. Tata basa Sunda Kiwari. First edition. Bandung: Yrama Widya.

Zoetmulder, P.J. 1950. De taal van het Adiparwa; Een grammaticale studie van het Oudjavaans. Bandung: Nix. [Verhandelingen van het Bataviaasch Genootschap van Kunsten en Wetenschappen 79.]

Zoetmulder, P.J. 1982. Old Javanese-English dictionary. 2 vols. 's-Gravenhage: Martinus Nijhoff.

\begin{abstract}
ABOUT THE AUTHORS
ADITIA GUNAWAN is a librarian at the National Library of Indonesia, specialized in Sundanese, Old Sundanese, and Old Javanese texts and manuscripts. He completed a Master in Texts and Linguistics at Inalco (Institut National des Langues et Civilisations Orientales), Paris (2016) and is currently pursuing his doctoral studies at the École Pratique des Hautes Études (EPHE) with the fellowship from EFEO through the project DHARMA (https://dharma.hypotheses. $\mathrm{org} /$ ). He has published several editions of Old Sundanese texts and articles related to the topic, among them Bhima Svarga: Teks Jawa Kuno abad ke-15 dan penurunan naskahnya (Jakarta: Perpusnas Press, 2019), "Nipah or Gebang? A philological and codicological study based on sources from West Java", Bijdragen tot de Taal-, Land en Volkenkunde 171/2-3 (2015: 249-280), and "Textiles in Old Sundanese texts", Archipel 98 (2019: 71-107). Aditia Gunawan is also a member of Indonesian association of Manuscript (Manassa) and Centre d'Asie du Sud-est (CASE). Aditia Gunawan can be reached at: aditia.gunawan@efeo.net.
\end{abstract}

EVI FUJI FAUZIYAH is an analyst and philologist at Badan Bahasa (National Language for Development and Cultivation), Ministry of Education and Culture of Republic of Indonesia. She was an undergraduate at Padjadjaran University 2009-2013. Currently she is taking her master in philology at the same university and preparing an edition of Old Sundanese text, Sang Hyang Tiga Ajñana, for her thesis. Evi Fuji Fauziyah can be contacted at: fuji.vi@gmail.com. 